\title{
Development and Regeneration in the Endocrine Pancreas
}

\author{
Ahmed Mansouri, ${ }^{1,2}$ \\ ${ }^{1}$ Research Group Molecular Cell Differentiation, Department Molecular Cell Biology, Max-Planck Institute for Biophysical Chemistry, \\ Am Fassberg 11, 37077 Goettingen, Germany \\ ${ }^{2}$ Department of Clinical Neurophysiology, University of Goettingen, Robert-Koch-Strasse 40, 37075 Goettingen, Germany
}

Correspondence should be addressed to Ahmed Mansouri, amansou@gwdg.de

Received 13 November 2012; Accepted 10 December 2012

Academic Editors: H. Galbo, R. Gasa, A. I. Torres, and A. O. L. Wong

Copyright () 2012 Ahmed Mansouri. This is an open access article distributed under the Creative Commons Attribution License, which permits unrestricted use, distribution, and reproduction in any medium, provided the original work is properly cited.

The pancreas is composed of two compartments that deliver digestive enzymes and endocrine hormones to control the blood sugar level. The endocrine pancreas consists of functional units organized into cell clusters called islets of Langerhans where insulinproducing cells are found in the core and surrounded by glucagon-, somatostatin-, pancreatic polypeptide-, and ghrelin-producing cells. Diabetes is a devastating disease provoked by the depletion or malfunction of insulin-producing beta-cells in the endocrine pancreas. The side effects of diabetes are multiple, including cardiovascular, neuropathological, and kidney diseases. The analyses of transgenic and knockout mice gave major insights into the molecular mechanisms controlling endocrine pancreas genesis. Moreover, the study of animal models of pancreas injury revealed that the pancreas has the propensity to undergo regeneration and opened new avenues to develop novel therapeutic approaches for the treatment of diabetes. Thus, beside self-replication of preexisting insulin-producing cells, several potential cell sources in the adult pancreas were suggested to contribute to beta-cell regeneration, including acinar, intraislet, and duct epithelia. However, regeneration in the adult endocrine pancreas is still under controversial debate.

\section{Introduction}

The pancreas is an important organ that produces digestive enzymes and hormones to control blood glucose homeostasis. Hence, the organ consists of two major compartments. The main part, the exocrine tissue is composed of acinar cells and an intricate ductal system to transport the digestive juice to the duodenum. Embedded within the exocrine tissues reside highly organized functional units called islets of Langerhans where five hormone secreting cells are clustered [1-5]. In the mouse, islets typically display a core of insulinproducing beta-cells surrounded by alpha, delta, PP, and epsilon cells, secreting the hormones glucagon, somatostatin, pancreatic polypeptide, and ghrelin, respectively [15].

During mouse pancreas genesis a complex and highly orchestrated molecular program acts to control the allocation of cell progenitors towards mature endocrine cells $[1,6,7]$. The delineation of the pancreatic fate is marked by the coexpression domain of the transcription factors $P d x 1$ and Ptfla at the foregut/midgut junction, where a ventral and a dorsal evaginations announce the first morphological sign of pancreas development $[6,8-10]$. Lineage tracing experiments clearly demonstrated that $P d x 1$-positive progenitor cells contribute to the formation of endocrine and exocrine compartment [11]. Similarly, all Ptf1a-positive cells generate all pancreatic derivatives [10]. In the absence of Ptfla gene activity pancreatic cells destined to form the ventral pancreas adopt a duodenal epithelium phenotype, indicating that Ptfla is required to confer endodermal progenitors with pancreatic fate by repressing the allocation to intestinal destiny [10]. The pancreatic epithelium undergoes growth, branching, and differentiation with the onset of the socalled secondary transition at embryonic day 13.5 (E13.5) of gestation [12]. At E12.5 fusion of ventral and dorsal pancreas occurs. Genetic lineage tracing experiments demonstrated that multipotent progenitor cells reside at the tip of the branching epithelium and are marked by the expression of Pdx1, Ptf1a, Cpal, and c-myc [13]. These multipotent progenitors differentiate into acinar, duct, and endocrine cells to eventually become restricted to exocrine fate after E14.0 of development $[5,13]$. 
A highly debated issue is whether endocrine progenitors exist in the adult pancreas. Several animal models of pancreas injury have been analyzed for their capacity to undergo regeneration [14-22]. In these animals endocrine cell regeneration was reported. Thus, various sources of islet neogenesis were proposed. It appears that one major and dominant mechanism to regenerate insulin-producing cells, under injured and physiological conditions, consists in the capacity of preexisting beta-cells to self-replicate [23-25]. In addition, intraislet progenitors as well as centroacinar cells have been suggested as a site of islet neogenesis [18, 19, 26, 27]. Moreover, several studies indicate that in the adult pancreas duct and/or duct-lining cells have the propensity to differentiate into endocrine cells and give rise to functional beta-cells [16, 28-33]. Of high interest is the observation that compromising the glucagon-signaling pathway is associated with alpha-cell regeneration [22]. Analyses of knockout mice lacking factors implicated in pancreas development have made the path for the establishment of protocols to generate insulin-producing cells from progenitor and/or embryonic stem cells [34].

\section{Factors Controlling Pancreatic Endocrine Progenitors}

The first signs of pancreas development appear as a dorsal and a ventral bulge at the foregut/midgut junction. Although at E9.5 few cells in the pancreatic epithelium start to express glucagon, and, 24 hours later some of these coexpress insulin, they do not appear to contribute to the mature endocrine pancreas [40]. However, glucagon has been shown to affect the differentiation of early insulin-expressing cells in the developing mouse pancreas $[41,42]$. It is first during the secondary transition at E13.5 where the amplification of endocrine cells takes place [12]. The expression of Fgf10 in the pancreatic mesenchyme is required for the proliferation of the pancreatic epithelium, where growth and branching in Fgf10-deficient mice are dramatically affected [43]. In addition, the gene activity of $I s l-1$ is necessary for the formation of the dorsal mesenchyme. Accordingly, in Isl1 mutant mice the dorsal mesenchyme is not formed, and islet cell genesis is affected [44]. Thus, it is important to notice that Isl-1 is necessary in the mesenchyme, as well as in the pancreatic epithelium for normal pancreas development [44].

All pancreatic endocrine progenitors are marked by the expression of the bHLH transcription factor $\operatorname{Ngn3}[45,46]$. In most organs Notch signaling was found to control cell fate decisions. This is also true for the pancreas, as documented by the expansion of endocrine progenitors in mice where Notch signaling is compromised. Accordingly, the loss of gene activity in Notch signaling components such as DLL1, RBPJ- $\kappa$, or Hes 1 is accompanied by a dramatic increase in the content of Ngn3-labeled cells [47, 48]. Moreover, the Notch downstream target Hes 1 was shown to bind to the proximal Ngn3 promoter and inhibit transcription [49]. On the other hand, sustained Notch signaling pathway in pancreatic progenitors where the expression of activated Notch is induced under the control of $P d x 1$ promoter prevents endocrine as well as exocrine differentiation [50]. Hence, in a recent study using genetic lineage tracing, Hes1-labeled cells were found to contribute to exocrine and endocrine cells in the developing pancreas [51]. Interestingly, Notch signaling not only activates Hes1, a repressor of Ngn3, but also promotes the expression of Sox9, an activator of Ngn3 [52]. This discrepancy is concealed by the recent finding demonstrating different level of Notch activity required to induce Sox9 and Hes 1 expression in the pancreas and thereby controls the segregation of cellular fates [52]. On the other hand it is interesting to notice that presenilins dose was also found to regulate the fate of pancreatic endocrine progenitors. $\mathrm{Ngn3}$-positive cells where presenilin was inactivated became fated to acinar cells [53]. Thus, during a narrow window of endocrine development Notch2 was identified as a crucial player, sustaining the selection of endocrine cell destiny by Ngn3, where it contributes to titrating RBP-J $\kappa$ from Ptfla [53].

Beside Notch also TGF- $\beta$ signaling appears to act on progenitor cells in the pancreas and GDF11 as well as Smad2 were found to affect pancreatic endocrine cell differentiation. In fact, in the absence of Gdf11 or Smad2 gene activity, an expansion of Ngn3-labeled cells was uncovered [54]. Thus, the expression of Hes1 in the pancreas of Gdf11 or Smad2 mutant mice was not altered, and suggesting that Notch and TGF- $\beta$ signaling may act in parallel pathways to control pancreatic endocrine cell progenitor expansion [54].

During mouse development pancreatic endocrine cell genesis is initiated by the activation of the bHLH transcription factor Ngn3 in the pancreatic epithelium. Ngn3 labels all endocrine progenitors $[45,46,55,56]$. Accordingly, Ngn3 was found necessary for the formation of the endocrine pancreas, and its forced expression under the control of the $P d x 1$ promoter is sufficient to promote the generation of all endocrine cells $[46,55]$. Interestingly, the early activation of $\mathrm{Ngn3}$ led to the production of mostly glucagon-labeled cells, while the induction of $\mathrm{Ngn3}$ at later stages of development promotes the formation of insulin, somatostatin, and PP cells [55]. However, by which molecular mechanism Ngn3 mediates endocrine fate choice is still unclear. For instance, the manipulation of $\mathrm{Ngn3}$ expression level in endocrine progenitors uncovered the critical role played by $\mathrm{Ngn3}$ expression threshold to promote an endocrine cell destiny [57]. It appears that high levels of $\mathrm{Ngn3}$ protein are necessary to engage pancreatic cell progenitors into the endocrine fate while pancreatic progenitors exhibiting low levels of $N g n 3$ give rise to acinar or duct cells. Thus, high level of $\mathrm{Ngn3}$ expression was suggested to possibly act in feedback loops involving lateral inhibition mechanism [57]. Moreover, $\mathrm{Ngn3}$ was shown to be involved in the initiation of the delamination of endocrine cells from the pancreatic epithelium, whereby effectors of epithelial mesenchymal transition (EMT) are activated to repress the expression of E-cadherin [58]. This is corroborated by a recent study showing that Ngn3-labeled progenitors play a role in controlling fate and morphogenesis of the pancreatic duct epithelium [59]. The role of $\mathrm{Ngn3}$ as a determinant of endocrine progenitors is further documented by its ability to activate the transcription of a number of genes acting in the process of differentiation 
and subtype specification of various pancreatic endocrine hormones. Such factors include Pax4, Nkx2.2, NueroD1, and the direct downstream target of $\mathrm{Ngn} 3$ insulinomaassociated 1 (Insm1) [3, 60-63]. Remarkably, in vivo clonal analysis in mice elegantly provided strong evidence that $\mathrm{Ngn} 3$ expressing cells are unipotent and low replicating cells [64]. This may have implications for the generation of insulinproducing cells from progenitor cells or embryonic stem cells.

Several other transcription factors control upstream of Ngn3 the development of the endocrine pancreas. Thus, the transcription factor Sox9 was found to label pancreatic multipotent progenitors, but its expression is downregulated in committed endocrine progenitors and differentiated cells [65]. In adult pancreas Sox9 is restricted to duct cells, and its loss uncovered a role upstream of $\mathrm{Ngn} 3$ in promoting progenitor cell proliferation, and survival [65]. Moreover, Sox9 was also suggested to mark those pancreatic epithelial cords in the developing pancreas that differentiate into exocrine and endocrine cells [66].

The transcription factor Nkx6.1 is expressed in pancreatic epithelium and is later confined to the developing beta-cell [67]. In mice lacking Nkx6.1 differentiating betacells are not formed, indicating that insulin-producing cell depletion occurs by apoptosis. Interestingly, Nkx2.2/Nkx6.1 compound mutants exhibit a similar phenotype to $\mathrm{Nkx} 2.2$, suggesting a role for Nkx2.2 upstream of Nkx6.1 [67]. Recent gain-of-function experiments where Nkx6.1 forced expression was induced in the endocrine pancreas revealed a notch-dependent and cross-inhibitory interaction mechanism operating between Nkx6.1 and Ptfla, to endow progenitor cells with ductal/endocrine or acinar cell destiny, respectively [68].

Genetic analysis has demonstrated that the transcription factors HNF1 $\beta$ and HNF6 label early pancreatic progenitors, act upstream of $\mathrm{Ngn3}$, and are thus required for the proper differentiation of Ngn3-expressing cells [69, 70]. Lineage tracing experiments using the Cre recombinase under the control of the HNF1 $\beta$ promoter provide clear evidence that HNF1 $\beta$ expression undergoes a developmentally regulated restriction [71]. First, HNF1 $\beta$ is found in pancreatic progenitors, subsequently becomes confined to those epithelial cells (termed also embryonic cord) that will give rise to ductal and endocrine cells, to eventually persist only in adult duct cells [71]. In summary, while Ngn3 marks endocrine progenitors, pancreatic epithelium expressing Sox $9, \operatorname{Hnf} 1 \beta$, or Cpa1 appear to label multipotent progenitors giving rise to all pancreatic cells and including endocrine lineage $[4,5$, 13, 22, 72]. Moreover, the further restriction of multipotent pancreatic progenitor to ductal and endocrine fate is marked by the mutual expression of Sox 9 and HNF $1 \beta$ in embryonic cord cells $[66,71]$. Thus, the allocation to different cell fates is clearly endowed by the differential expression of transcription factors.

Finally, in contrast to previously assumed, $\mathrm{Ngn3}$ expression has been found sustained in adult islets, and genetic analysis provided evidence for a role for this factor in contributing to islet maturation and preserving islet function [73].

\section{Endocrine Cell Subtype Specification}

Following Ngn3 activation a battery of transcription factors is induced to promote the allocation of endocrine progenitors to distinct hormones producing cells $[1-3,7]$. Most of these factors appear at early stages of development in the pancreatic epithelium and progressively exhibit a more restricted expression pattern with advanced endocrine cell genesis. The first induced factors during the initiation of pancreatic endocrine differentiation program, and downstream of Ngn3, are NeuroD1 (BEATA2), Insm1, and Rfx6 which appear as immediate targets of $\mathrm{Ngn3}$ [63, 74-77]. Accordingly, the loss of Insm1 or Rfx6 is accompanied by the persistence of mostly nondifferentiated islet progenitors. Interestingly, similar to $\mathrm{Ngn3}$, the forced expression of NeuroD1 in pancreatic progenitors under the control of the $P d x 1$ promoter results into differentiation to hormone producing cells, while the of loss function provokes a of loss insulin producing beta-cells by apoptosis $[46,74]$.

Subsequently, endocrine progenitors are allocated to the different hormone producing cells. The molecular mechanism underlying endocrine cell subtype specification is still not completely understood. However, the analysis of gainand loss-of-function mutant mice revealed a complex crossregulatory interaction between transcription factors and involving very often reciprocal inhibitory mode of operation. This is illustrated for two transcription factors, Pax4 and Arx, playing a crucial role in the specification of insulin and glucagon cell destiny, respectively $[1,2,7]$. Pax4, a paired box-containing factor, is first detected in the pancreatic epithelium and later restricted to the beta/delta-cell lineage $[78,79]$. A further study using lineage tracing indicates that Pax4-positive cells represent specified endocrine progenitors that may contribute equally to islet cells [80]. Arx is also found in the pancreatic epithelium and later confined to alpha and PP cells [81]. Pax4-deficient pancreas exhibit normal islet morphology but is devoid of insulin-producing beta-cells and somatostatin-labeled delta-cells. Instead, a proportionally increased number of glucagon expressing cells is accumulating in the core of the islet [78]. In contrast, in Arx-deficient animals alpha-cells do not develop, whereas an augmentation of the beta- and delta-cell content is detected [81]. It appears that Pax4 and Arx mutant mice suffer from opposite phenotypes in the endocrine pancreas, clearly suggesting that these two factors interact with each other. These findings sustain a working model where Pax4 and Arx are first expressed in the same proendocrine cell and undergo a reciprocal inhibitory interaction to endow endocrine progenitors with a beta-/delta-cell fate or alphacell destiny, respectively. This is corroborated by the ability of the Pax4 factor to bind Arx promoter sequences and repress Arx transcription, and similarly Arx protein to suppress Pax4 transcription by binding to Pax4 promoter [82]. The signal that triggers the segregation of Pax4- and Arx-expressing cells is not known. However, the repression of Arx in committed beta-cells is mediated by methylation of Arx locus [83]. Arx is thus hypomethylated in alpha-cells, as well as in Dnmt1-deficient beta-cells that undergo conversion to alpha-cell destiny [83]. It is also worth mentioning that Isl-1 
was recently found to regulate Arx transcription in alphacells [84].

The molecular characterization of pancreata, derived from mice lacking Pax4 and/or Arx, has provided further insights into the molecular mechanisms controlling pancreatic endocrine cell subtype specification and demonstrated that, in a second round of endocrine cell allocation, a similar interaction may occur between Pax 4 and a factor X which may contribute to the promotion of beta- and delta-cell destiny, respectively. Gain-of-function experiments where Arx was misexpressed in adult beta-cells provided further insight that Arx is also sufficient to force the alpha- and PP-cell fate even in mature beta-cells [85]. Along the same line of evidence, the sole forced expression of Pax4 in glucagon-producing cells is able to reprogram alphacells into functional beta-cells that can counter chemically induced diabetes. Remarkably, the forced expression of Pax4 also triggered an $\mathrm{Ngn3}$-dependent and duct-derived cycle of alpha-cell regeneration (see later).

Beside Pax 4 and Arx, Nkx2.2 was found to play an important role in endocrine cell differentiation. Thus, $\mathrm{Nkx} 2.2$ is detected at E9.5 in the dorsal pancreatic epithelium and later confined to beta-, alpha-, and PP-cells [86]. Hence, in the absence of this factor, alpha- and beta-cell development is severely affected, while the number of ghrelin-positive cells is increased. Instead, immature beta-cells are detected in $\mathrm{Nkx} 2.2^{-/-}$pancreas, suggesting an important function for Nkx2.2 in beta-cell differentiation [86]. Interestingly, the transcription of Arx was found enhanced in the pancreata of these mutants [87-89]. Analysis of pancreata derived from mice lacking functional Arx and Nkx2.2 support the idea that $\mathrm{Nkx} 2.2$ acts to reinforce the transcriptional networks initiated by Pax 4 and Arx in early committed beta- and alpha-cells, respectively. Moreover, it appears that the coupled function of Pax4 and Nkx2.2 is to counteract Arx gene activity in early committed beta-cells [88, 89]. Remarkably, Nkx2.2 was found engaged in a repressor complex including DNMT3, Grg3, and HDAC1, to promote beta-cell differentiation, and thereby inhibiting alpha-cell destiny [90].

The predominant role of Pax4 and Nkx2.2 in beta-cell differentiation is further documented by a study showing that in the absence of Pax4, Nkx2.2, or both factors, the expression of beta-cell markers including insulin, $P d x 1$, HB9, and Nkx6.1 is abolished. Moreover, the two factors act in parallel to promote beta-cell differentiation program [79].

Several transcription factors such as MafA, MafB, Pax6, Pax4, Nkx6.1, $P d x 1$, and Isl-1 are still expressed in the adult pancreas and appear to sustain endocrine cell fate. MafA and MafB factors display a developmentally highly regulated expression pattern that correlates with beta- and alpha-cell maturation, respectively [91]. Accordingly, MafB expression starts in the pancreatic epithelium at E10.5 and is found in developing beta- and alpha-cells to eventually become confined to glucagon-expressing cells after partum [9294]. In contrast, MafA-labeled cells first appear at E13.5 in insulin-positive cells, and MafA expression persists in adult beta-cells $[92,95]$. The dominant role of MafA in beta-cell maturation is documented by the regulation of its activity by several pancreatic transcription factors and including Nkx2.2, Nkx6.1, NeurD1, Foxa2, Pdx1, Pax6, MafB, and Isl-1 [91]. Moreover, the forced expression of MafA together with $N g n 3$ and $P d x 1$ is able to convert acinar cells into functional beta-cells in vivo [35].

Pax6 is already detected in the pancreatic epithelium at E10.5, and its absence provokes a decrease of all islets cells, with the exception of ghrelin-labeled cells [9698]. However, the conditional inactivation of Pax6 in the endocrine pancreas does not affect endocrine cell genesis and reveals that this factor is required for maintaining cell differentiation [99]. Accordingly, the beta-cell determinant factor Nkx2.2 is necessary to sustain the proper expression level of Pax6 in beta-cells [79]. Nkx6.1 expression in adult beta-cells was shown to stimulate their proliferation in vitro [100]. However, the forced expression of this factor in adult beta-cells of transgenic mice has no impact on beta-cell proliferation or regeneration [101]. Pax4 function in adult beta-cells is still unclear, notwithstanding Pax4 was shown to play a role in vitro in the proliferation and survival of insulin-producing cells [102]. Finally, Isl-1 is required in the pancreatic mesenchyme and epithelium to promote pancreas development [44]. Recent study revealed the role of Isl-1 in the endocrine pancreas where it affects proliferation and survival of islet cells. Moreover, MafA a beta-cell maturation determinant was identified as a direct target of Isl-1 [103].

While the expression of $P d x 1$ labels all pancreatic progenitors, it eventually becomes confined to the developing betacell where it persists in the adult pancreas. Accordingly, the global loss of $P d x 1$ is accompanied by the development of a rudimentary pancreatic bud $[8,9]$, while the conditional inactivation reveals a role for this factor in sustaining the beta-cell phenotype through the suppression of glucagon gene activity [104]. Remarkably, the forced expression of $P d x 1$ in endocrine progenitors is able to convert alpha- into beta-cells, whereas alpha-cells are resistant to beta-cell reprogramming through $P d x 1$ activity [105]. It is interesting to remind that, in contrast to $P d x 1$, the sole expression of Pax4 is sufficient to reprogram alpha-cells into insulin-producing beta-cells that counter chemically induced diabetes [32].

\section{Endocrine Cell Regeneration in the Adult Pancreas}

Understanding the molecular mechanisms controlling endocrine pancreas development, those operating during islet neogenesis in pancreatic injury models may open new avenues to develop novel approaches for the treatment of diabetes. Several independent studies using various models of pancreatic injury revealed that regeneration may occur in the adult pancreas $[22,106,107]$. Thus, different models and mechanisms of endocrine cell regeneration were proposed. Moreover, the mechanisms underlying endocrine cell neogenesis appear to depend not only on the type but also on the extent of injury [22]. Therefore, it is still controversially debated whether stem/progenitor cells exist in the adult pancreas, and if so where do these may reside (Figure 1). 


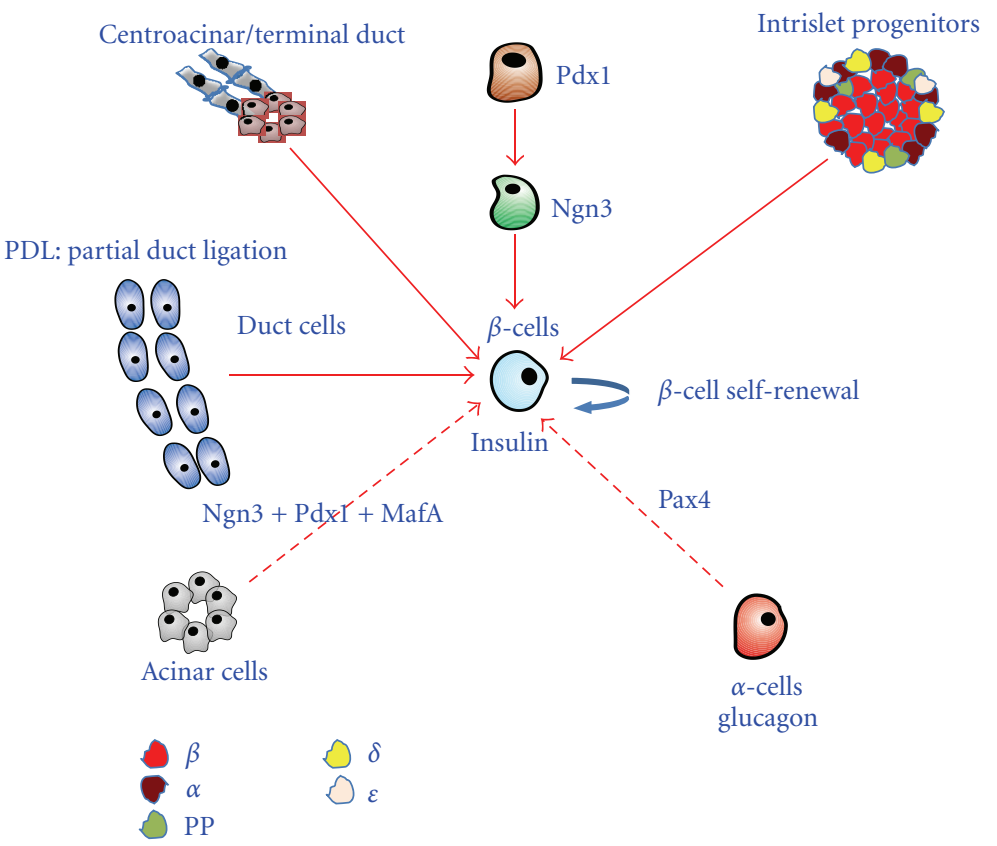

FIGURE 1: Regeneration routes in the adult endocrine pancreas. During normal development $P d x 1$-marked cells are fated to generate pancreas tissue. Subsequently, a small proportion of these cells labeled by the bHLH factor Ngn3 acquire endocrine cell destiny and give rise to hormone-producing cells, and consisting of beta-, alpha-, delta-, PP-, and epsilon-cells, producing insulin, glucagon, somatostatin, pancreatic polypeptide, and ghrelin, respectively. Following pancreatic injury different sources of stem/progenitor cell were proposed. It is well accepted that beta-cells are able to self-renew under physiological conditions or following pancreatic injury. However, other sources of beta-cell regeneration are under debate. In several animal models duct/duct-lining cells appear as the dominant source where stem/progenitor cells may reside. Interestingly, the forced expression of $P d x 1, N g n 3$, and MafA is able to allow transdifferentiation of acinar cells into insulin-producing cells in vivo [35]. Global ablation of beta-cells using diphtheria toxin led to some conversion of alpha- to betacells [20]. A more robust transdifferentiation of alpha- to beta-cells was observed following the combination of pancreatic duct ligation and alloxan-induced beta-cell injury [36, 37]. On the other hand, the misexpression of a single factor, Pax4 in alpha-cells, was able to endow these with functional beta-cell characteristic, and counter chemically induced diabetes in mice. This study clearly uncovered the robustregenerative capacity of alpha-cells and provides a possible new source for generating beta-cells to develop revolutionary approaches to treat diabetes $[32,38,39]$. PDL: pancreatic duct ligation.

The major mechanism leading to regeneration of insulinproducing cells in the adult pancreas is self-renewal of preexisting beta-cells. However, in several studies also intraislet progenitors were proposed to contribute to islet neogenesis $[18,19,26,36]$. Although lineage tracing experiments have provided strong evidence that preexisting acinar cells do not contribute to endocrine cells [108], acinar AR42J cells were shown to give rise to insulin- and glucagon-producing cells, when treated with betacellulin, activin, or glucagonlike peptide $[109,110]$ (for review see [22]). In addition, centroacinar/terminal duct cells were found to express stem cell markers and may therefore represent a source of progenitor cells engaged in islet regeneration $[29,111]$. The transdifferentiation of acinar cells into functional beta-cells in mice can be induced by the ectopic combined expression of three factors, $P d x 1, N g n 3$, and MafA, and clearly document the inherent capacity of the acinar compartment to give rise to islet cells [35]. This is corroborated by a recent study in zebrafish, demonstrating that suppressing Ptfla gene activity in the acinar compartment of postembryonic pancreas is able to promote transdifferentiation into endocrine cells [112]. In addition, in several studies of pancreatic injury models, and transgenic mice, progenitor/stem cells were suggested to reside in the duct epithelium, where cells expressing the proendocrine marker Ngn3 were detected. Of interest is further the demonstration of the robust regeneration capacity of alpha-cells, following alterations in the glucagon signaling pathway [22].

\section{Self-Replication of Preexisting Beta-Cells}

It is now well accepted that preexisting insulin-producing cells have the ability to undergo self-renewal under normal physiological condition $[23,113]$ and following injury. Thus, genetic as well as DNA analog-based lineage tracing experiments have provided strong evidence for the propensity of the beta-cell to self-replicate in different injury models, including pancreatectomy, diphtheria-toxin-induced betacell ablation, and pancreatic duct ligation [17, 23-25]. This is also true for beta-cell replenishment occurring in animals where c-myc conditional overexpression induced beta-cell apoptosis, and leading to diabetes. Following inactivation of c-myc overexpression insulin-producing cells regenerate 
and diabetes is reversed [114]. These studies are further sustained by the finding that, following partial pancreatectomy in mice, beta-cell regeneration occurs in the absence of the proendocrine marker Ngn3 reactivation [115]. This is in agreement with a report showing that miRNAs accumulate in the adult pancreas subjected to pancreatectomy, and some of these were identified as candidates with the capacity to block Ngn3 expression [116]. Furthermore, it appears that the increase of beta-cell mass in obese individuals and during pregnancy is driven by the amplification of preexisting betacells [117]. Of interest is the observation that the endocrine tumor suppressor Menin is downregulated in the islets during pregnancy and leading to the growth of beta-cell mass [118]. In addition, STAT5, growth hormones, prolactin, and foxM1 were shown to promote beta-cell self-renewal during pregnancy [117]. However, non-beta-cell progenitors were also reported to contribute to the increase in betacell mass during pregnancy in mice [119]. Furthermore, it has also to be mentioned that, following streptozotocinmediated islet injury, and during aging in mice, a lineagetracing study using a similar approach as described by Dor et al. [23] provided evidence that, beside beta-cell selfrenewal, intraislet progenitors may participate in beta-cell regeneration [18].

Beta-cell proliferation is age dependent, for instance, in rodents, and regeneration capacity is therefore dramatically reduced in older mice, as compared to young animals [120123]. Of note is the role of cell-cycle regulators in controlling beta-cell replication, documented by the reduced islet size, and beta-cell replication potential found in the pancreas of cyclin D1, 2-deficient mice [124, 125]. Beta-cell proliferation may also in human contribute to the increase in beta-cell mass, as implicated from in vitro experiments where human islets were forced to express the Cdk4 gene [126].

\section{Facultative Stem Cells May Reside in the Duct Epithelium}

In addition to beta-cell self-renewal other mechanisms may act to promote endocrine cell regeneration in the adult pancreas. Thus, several sources of progenitor/stem cells in the adult pancreas were proposed to contribute to islet cell neogenesis and give rise to functional beta-cells. The most prominent model being the delamination of endocrine cells is residing in the duct epithelium, where an Ngn3-dependent endocrine cell neogenesis is initiated. Using several models of pancreas injury, and including transgenic animals, endocrine cells expressing insulin, glucagon, but also Ngn3, as well as $P d x 1$ labeled cells were detected in the ductal epithelium, providing evidence that indeed ductal lining structures may comprise multipotent facultative stem/progenitor cells [22, $107,127,128]$. In fact, partial duct ligation (PDL) in the pancreas was accompanied by the emergence of $\mathrm{Ngn3}$ labeled duct cells that are able to differentiate in all endocrine cells [30]. This is corroborated by a study using carbonic anhydrase II promoter to genetically mark duct derivatives in PDL injury model and demonstrating that duct cells have indeed the capacity to give rise to endocrine as well as exocrine cells [31]. The combination of PDL with the ablation of beta-cells through alloxan also resulted in robust beta-cell regeneration. However, the newly formed betacells do not appear to derive from the duct epithelium but through direct conversion of alpha-cells [36]. Hence, betacell neogenesis was suggested to occur from intraislet progenitors [36]. On the other hand, another mouse model, where alpha-cells were directly converted into functional betacells by the conditional misexpression of the transcription factor Pax4 in glucagon-producing cells, resulted in glucagon neogenesis through the activation of duct-derived facultative stem cells $[32,38]$. This clearly illustrates the impact of the type and extent of pancreatic injury under study on the regeneration process. Of note is the observation that beta-cell neogenesis also occurs in BETA2/NeuroD1 knockout mice that survived to adulthood. Newly generated beta-cells in these animals were found to derive from two distinct sources, by self renewal of preexisting beta-cells, and from the duct epithelium [129].

Lineage tracing experiments using $\operatorname{Hnf} 1 \beta$ driven Cre recombinase to label duct progenitors in PDL- or alloxan/EGF/gastrin-injured adult pancreas revealed no contribution of duct epithelium to endocrine regeneration $[71,130]$. Similarly, in the adult non-injured pancreas Muc1 lineage-labeled cells were only found to participate in the formation of duct/acinar cells [131]. Moreover, also Sox9 lineage-labeled cells in various pancreatic injury models did not uncover any endocrine cells derived from duct epithelium [132]. This contrasts the findings where Carbonic anhydrase II was used for genetic lineage tracing, and may suggest that $\mathrm{Hnf} 1 \beta \mathrm{Cre}$, Sox9Cre, as well as Muc1Cre do not really mark all duct cells [31]. It is therefore reasonable to assume that progenitor/stem cells may consist of a rare population and/or reside near duct structures (duct lining). Moreover, these discrepancies clearly suggest that there is a need for additional pancreatic injury models as well for transgenic mouse lines allowing lineage tracing of duct and/or acinar cells [133]. The finding that duct cells may contain facultative stem cells [128] implicates that cells has to delaminate from these epithelial structures and migrate to populate the islets of Langerhans.

\section{Glucagon for Use as Potential Stem Cell of Endocrine Cell Regeneration}

Several studies in mice clearly provide strong evidence that defective or altered glucagon-signaling pathway ultimately triggers regeneration of glucagon-producing alphacells. This has been shown in several animal models where glucagon shortage occurs. As mentioned above the forced expression of Pax4 in glucagon-expressing alpha-cells is able to convert these into functional beta-cells that counter chemically induced diabetes in mice $[32,38]$. Transgenic mice ectopically expressing Pax4 in glucagon-producing cells develop an age-dependent increase in islet size and betacell mass. Remarkably, the so induced transdifferentiation of alpha-cells revealed that, in order to compensate the 
thereby compromised glucagon signaling, alpha-cell neogenesis occurred in these mice. As a consequence a permanent cycle of alpha-cell/regeneration and conversion into betacell, was suggested, eventually contributing to increased islet size $[32,38]$. The observed alpha-cell renewal in Pax4transgenic mice is corroborated by glucagon hyperplasia observed in mice lacking glucagon receptor, prohormone convertase 2, or glucagon gene-derived peptides [134-136]. Moreover, glucagon supplementation is able to affect the phenotypes of oversized islets and/or glucagon hyperplasia observed in these mice [32, 137]. These studies clearly establish that deregulated glucagon signaling results in alphacell neogenesis, and providing clear evidence that endocrine cell regeneration can be induced in the adult pancreas. Interestingly, mice lacking prohormone convertase 2 gene activity, beside glucagon hyperplasia, also islet neogenesis was reported [138].

Using diphtheria toxin to globally ablate glucagon cells in the adult pancreas does not provoke glucagon neogenesis [139]. It appears that as few as two percent of alpha-cell mass cells are sufficient to produce enough glucagon so that glucagon signaling remains unaffected [139]. Notwithstanding, in several animals models described above, glucagon shortage was compensated by alpha-cell amplification. However, it is not clear which signal(s) is triggering alpha-cell neogenesis. It is interesting to notice that the loss of Menin gene activity in alpha-cells provokes their subsequent conversion into insulin-producing beta-cells leading to insulinoma formation [140]. In these animals glucagon-producing cells were shown to undergo cell proliferation [140]. Remarkably, spontaneous transdifferentiation of alpha-cells into betacells was reported to occur in mice with global ablation of insulin-producing beta-cells by diphtheria toxin [20] Why such alpha-cell transdifferentiation does not appear to contribute to beta-cell replenishment in diabetic animals remains elusive. It is possible that a signal is required to induce such transdifferentiation mechanism. Glucagon itself may represent such a signal, since as stated above, glucagon supplementation affects the observed alterations of alphacell hyperplasia [32, 137]. Remarkably, as reviewed by Liu and Habener, alpha-cell hyperplasia is observed in animals lacking insulin-producing cells such as in Pax4-deficient mice, or where beta-cells were subjected to injury [141].

In mice forced to express Pax4 in alpha-cells, duct epithelium was identified as the source of newly generated glucagon-producing cells in an Ngn3-dependent manner [32]. Moreover, in glucagon receptor knockout mice glucagon-labeled cells were detected in the duct epithelium [134], and the expression of the proendocrine marker, Ngn3, was reactivated in the adult pancreas of these mice [32]. In animals lacking Prohormone convertase 2 gene activity increased alpha-cell proliferation and islet neogenesis were reported [138]. Therefore, it is possible that alpha-cell regeneration as well as alpha-cell self-replication may occur in these animals suffering from alterations in glucagonsignaling pathway. Interestingly, using $\mathrm{db} / \mathrm{db}$ mice as a model for type II diabetes, it has been recently reported that insulin and glucagon may regulate alpha-cell proliferation [142]. It is important here to recall that, also in other pancreatic injury models such as duct ligation, and streptozotocin-induced beta-cell depletion, stem/progenitor cells were found to reside in the duct epithelium [30].

Although some genetic lineage tracing studies in normal and injured animal models have provided no evidence for the contribution of duct or acinar cells to the regeneration of islet cells in the adult pancreas, the alterations observed in mice, where glucagon signaling is affected, clearly indicate that at least glucagon cells are able to regenerate. Remarkably, it has also been reported that in the islets of Type I diabetes patients, an increase in alpha-cell number was detected [143]. Moreover, this is also true for the islets of type I diabetes induced in mice by streptozotocin depletion of beta-cells [144]. All these studies may suggest that glucagon-producing alpha-cells could potentially be used as a source for the generation of insulin-producing cells to replace depleted beta-cells in diabetic patients. Although during normal endocrine pancreas genesis adult insulin- and glucagon-producing cells differentiate from two independent cell lineages, alpha-cells may still constitute a stem cell pool in the adult pancreas. As stated earlier glucagon has been shown to affect the first wave of differentiation of insulinexpressing cells in the developing mouse pancreas [41]. Interestingly, it has been recently proposed that alpha-cells are more plastic and may have the capacity to dedifferentiate to acquire a Pro-alpha-cell state and give rise to beta-cells [145]. This paracrine/autocrine regeneration model suggests that injured beta-cells produce the stromal cell-derived factor 1 (SDF-1) that triggers the dedifferentiation of mature alphacells into the Pro-alpha-cell and ensure their proliferation and survival. These Pro-alpha cells are characterized by the expression of the GLP1 and PC1/3 and may acquire mature beta-cell characteristics including the expression of $P d x 1$, Pax6, and MafA [145]. In order to induce the conversion of alpha- into beta-cells the expression of Pax4 has to be favored at the expense of Arx. Identifying the putative signal(s) that may trigger alpha-cell neogenesis, but also those that normally may act to block alpha-cell conversion into betacells in diabetic animals, is therefore of fundamental interest to develop new approaches for the treatment of diabetes.

Finally, although still controversial, most of the studies clearly provide strong evidence for the capacity of the adult endocrine pancreas to undergo regeneration. Several sources of islet cell neogenesis were proposed, and it appears that multiple mechanisms may act during this process. Future studies require novel pancreas injury models to uncover the common dominator of endocrine cell regeneration. Of special interest is the capacity of glucagon cells to regenerate, making alpha-cells as a possible progenitor cell that is prone to transdifferentiation into functional beta-cells.

\section{Acknowledgments}

The author would like to thank P. Collombat for fruitful discussions, the Max-Planck Society, the Juvenile Diabetes Research Foundation, JDRF, the Federal Ministry for Education and Research, BMBF (01KU0906), and the Dr. Helmut Storz Foundation for financial support. 


\section{References}

[1] P. Collombat, P. Serup, and A. Mansouri, "Specifying pancreatic endocrine cell fates," Mechanisms of Development, vol. 123, no. 7, pp. 501-512, 2006.

[2] L. C. Murtaugh, "Pancreas and beta-cell development: from the actual to the possible," Development, vol. 134, no. 3, pp. 427-438, 2007.

[3] J. M. Oliver-Krasinski and D. A. Stoffers, "On the origin of the $\beta$ cell," Genes and Development, vol. 22, no. 15, pp. 1998 2021, 2008.

[4] F. C. Pan and C. Wright, "Pancreas organogenesis: from bud to plexus to gland," Developmental Dynamics, vol. 240, no. 3, pp. 530-565, 2011.

[5] S. Rieck, E. D. Bankaitis, and C. V. E. Wright, "Lineage determinants in early endocrine development," Seminars in Cell and Developmental Biology, vol. 23, no. 6, pp. 673-684, 2012.

[6] M. A. Guney and M. Gannon, "Pancreas cell fate," Birth Defects Research C, vol. 87, no. 3, pp. 232-248, 2009.

[7] G. K. Gittes, "Developmental biology of the pancreas: a comprehensive review," Developmental Biology, vol. 326, no. 1, pp. 4-35, 2009.

[8] J. Jonsson, L. Carlsson, T. Edlund, and H. Edlund, "Insulinpromoter-factor 1 is required for pancreas development in mice," Nature, vol. 371, no. 6498, pp. 606-609, 1994.

[9] M. F. Offield, T. L. Jetton, P. A. Labosky et al., "PDX-1 is required for pancreatic outgrowth and differentiation of the rostral duodenum," Development, vol. 122, no. 3, pp. 983995, 1996.

[10] Y. Kawaguchi, B. Cooper, M. Gannon, M. Ray, R. J. MacDonald, and C. V. E. Wright, "The role of the transcriptional regulator Ptfla in converting intestinal to pancreatic progenitors," Nature Genetics, vol. 32, no. 1, pp. 128-134, 2002.

[11] G. Gu, J. R. Brown, and D. A. Melton, "Direct lineage tracing reveals the ontogeny of pancreatic cell fates during mouse embryogenesis," Mechanisms of Development, vol. 120, no. 1, pp. 35-43, 2003.

[12] R. L. Pictet, W. R. Clark, R. H. Williams, and W. J. Rutter, "An ultrastructural analysis of the developing embryonic pancreas," Developmental Biology, vol. 29, no. 4, pp. 436-467, 1972.

[13] Q. Zhou, A. C. Law, J. Rajagopal, W. J. Anderson, P. A. Gray, and D. A. Melton, "A multipotent progenitor domain guides pancreatic organogenesis," Developmental Cell, vol. 13, no. 1, pp. 103-114, 2007.

[14] J. P. Mordes and A. A. Rossini, "Animal models of diabetes," American Journal of Medicine, vol. 70, no. 2, pp. 353-360, 1981.

[15] L. Bouwens and G. Klöppel, "Islet cell neogenesis in the pancreas," Virchows Archiv, vol. 427, no. 6, pp. 553-560, 1996.

[16] S. Bonner-Weir and A. Sharma, "Pancreatic stem cells," Journal of Pathology, vol. 197, pp. 519-526, 2002.

[17] T. Nir, D. A. Melton, and Y. Dor, "Recovery from diabetes in mice by $\beta$ cell regeneration," Journal of Clinical Investigation, vol. 117, no. 9, pp. 2553-2561, 2007.

[18] H. Liu, Y. Guz, M. H. Kedees, J. Winkler, and G. Teitelman, "Precursor cells in mouse islets generate new $\beta$-cells in vivo during aging and after islet injury," Endocrinology, vol. 151, no. 2, pp. 520-528, 2010.

[19] Y. Guz, I. Nasir, and G. Teitelman, "Regeneration of pancreatic $\beta$ cells from intra-islet precursor cells in an experimental model of diabetes," Endocrinology, vol. 142, no. 11, pp. 49564968, 2001.
[20] F. Thorel, V. Népote, I. Avril et al., "Conversion of adult pancreatic $\alpha$-cells to $\beta$-cells after extreme $\beta$-cell loss," Nature, vol. 464, no. 7292, pp. 1149-1154, 2010.

[21] A. Lechner and J. F. Habener, "Stem/progenitor cells derived from adult tissues: potential for the treatment of diabetes mellitus," American Journal of Physiology, vol. 284, no. 2, pp. E259-E266, 2003.

[22] P. Collombat, X. Xu, H. Heimberg, and A. Mansouri, "Pancreatic beta-cells: from generation to regeneration," Seminars in Cell and Developmental Biology, vol. 21, no. 8, pp. 838-844, 2010.

[23] Y. Dor, J. Brown, O. I. Martinez, and D. A. Melton, "Adult pancreatic $\beta$-cells are formed by self-duplication rather than stem-cell differentiation," Nature, vol. 429, no. 6987, pp. 4146, 2004.

[24] K. Brennand, D. Huangfu, and D. Melton, "All beta cells contribute equally to islet growth and maintenance," PLoS biology, vol. 5, no. 7, p. e163, 2007.

[25] M. Teta, M. M. Rankin, S. Y. Long, G. M. Stein, and J. A. Kushner, "Growth and regeneration of adult beta cells does not involve specialized progenitors," Developmental Cell, vol. 12, no. 5, pp. 817-826, 2007.

[26] A. Fernandes, L. C. King, Y. Guz, R. Stein, C. V. E. Wright, and G. Teitelman, "Differentiation of new insulin-producing cells is induced by injury in adult pancreatic islets," Endocrinology, vol. 138, no. 4, pp. 1750-1762, 1997.

[27] R. De Haro-Hernández, L. Cabrera-Muñoz, and J. D. Méndez, "Regeneration of $\beta$-cells and neogenesis from small ducts or acinar cells promote recovery of endocrine pancreatic function in alloxan-treated rats," Archives of Medical Research, vol. 35, no. 2, pp. 114-120, 2004.

[28] M. Li, J. I. Miyagawa, K. Yamamoto et al., “ $\beta$ cell neogenesis from ducts and phenotypic conversion of residual islet cells in the adult pancreas of glucose intolerant mice induced by selective alloxan perfusion," Endocrine Journal, vol. 49, no. 5, pp. 561-572, 2002.

[29] K. Y. Hayashi, H. Tamaki, K. Handa, T. Takahashi, A. Kakita, and S. Yamashina, "Differentiation and proliferation of endocrine cells in the regenerating rat pancreas after $90 \%$ pancreatectomy," Archives of Histology and Cytology, vol. 66, no. 2, pp. 163-174, 2003.

[30] X. Xu, J. D’Hoker, G. Stangé et al., "Beta cells can be generated from endogenous progenitors in injured adult mouse pancreas," Cell, vol. 132, no. 2, pp. 197-207, 2008.

[31] A. Inada, C. Nienaber, H. Katsuta et al., "Carbonic anhydrase II-positive pancreatic cells are progenitors for both endocrine and exocrine pancreas after birth," Proceedings of the National Academy of Sciences of the United States of America, vol. 105, no. 50, pp. 19915-19919, 2008.

[32] P. Collombat, X. Xu, P. Ravassard et al., "The ectopic expression of Pax4 in the mouse pancreas converts progenitor cells into alpha and subsequently beta cells," Cell, vol. 138, no. 3, pp. 449-462, 2009.

[33] J. H. Lee, J. Jo, A. A. Hardikar, V. Periwal, and S. G. Rane, "Cdk4 regulates recruitment of quiescent $\beta$-cells and ductal epithelial progenitors to reconstitute $\beta$-cell mass," PLoS ONE, vol. 5, no. 1, Article ID e8653, 2010.

[34] E. Kroon, L. A. Martinson, K. Kadoya et al., "Pancreatic endoderm derived from human embryonic stem cells generates glucose-responsive insulin-secreting cells in vivo," Nature Biotechnology, vol. 26, no. 4, pp. 443-452, 2008.

[35] Q. Zhou, J. Brown, A. Kanarek, J. Rajagopal, and D. A. Melton, "In vivo reprogramming of adult pancreatic exocrine cells to $\beta$-cells," Nature, vol. 455, no. 7213, pp. 627-632, 2008. 
[36] C. H. Chung, E. Hao, R. Piran, E. Keinan, and F. Levine, "Pancreatic $\beta$-cell neogenesis by direct conversion from mature $\alpha$-cells," Stem Cells, vol. 28, no. 9, pp. 1630-1638, 2010.

[37] C. H. Chung and F. Levine, "Adult pancreatic alpha-cells: a new source of cells for beta-cell regeneration," The Review of Diabetic Studies, vol. 7, no. 2, pp. 124-131, 2010.

[38] P. Collombat and A. Mansouri, "Turning on the $\beta$-cell identity in the pancreas," Cell Cycle, vol. 8, no. 21, pp. 3450 3451, 2009.

[39] M. Courtney, A. Pfeifer, K. Al-Hasani et al., "In vivo conversion of adult $\alpha$-cells into $\beta$-like cells: a new research avenue in the context of type 1 diabetes," Diabetes, Obesity and Metabolism, vol. 13, no. 1, pp. 47-52, 2011.

[40] P. L. Herrera, "Adult insulin- and glucagon-producing cells differentiate from two independent cell lineages," Development, vol. 127, no. 11, pp. 2317-2322, 2000.

[41] K. Prasadan, E. Daume, B. Preuett et al., "Glucagon is required for early insulin-positive differentiation in the developing mouse pancreas," Diabetes, vol. 51, no. 11, pp. 3229-3236, 2002.

[42] P. M. Vuguin, M. H. Kedees, L. Cui et al., "Ablation of the glucagon receptor gene increases fetal lethality and produces alterations in islet development and maturation," Endocrinology, vol. 147, no. 9, pp. 3995-4006, 2006.

[43] A. Bhushan, N. Itoh, S. Kato et al., "Fgf10 is essential for maintaining the proliferative capacity of epithelial progenitor cells during early pancreatic organogenesis," Development, vol. 128, no. 24, pp. 5109-5117, 2001.

[44] U. Ahlgren, S. L. Pfaff, T. M. Jessell, T. Edlund, and H. Edlund, "Independent requirement for ISL1 in formation of pancreatic mesenchyme and islet cells," Nature, vol. 385, no. 6613, pp. 257-260, 1997.

[45] G. Gradwohl, A. Dierich, M. LeMeur, F. Guillemot, and F. Guillemot, "Neurogenin3 is required for the development of the four endocrine cell lineages of the pancreas," Proceedings of the National Academy of Sciences of the United States of America, vol. 97, no. 4, pp. 1607-1611, 2000.

[46] V. M. Schwitzgebel, D. W. Scheel, J. R. Conners et al., "Expression of neurogenin3 reveals an islet cell precursor population in the pancreas," Development, vol. 127, no. 16, pp. 3533-3542, 2000.

[47] Å. Apelqvist, H. Li, L. Sommer et al., "Notch signalling controls pancreatic cell differentiation," Nature, vol. 400, no. 6747, pp. 877-881, 1999.

[48] J. Jensen, E. E. Pedersen, P. Galante et al., "Control of endodermal endocrine development by Hes-1," Nature Genetics, vol. 24, no. 1, pp. 36-44, 2000.

[49] J. C. Lee, S. B. Smith, H. Watada et al., "Regulation of the pancreatic pro-endocrine gene neurogenin3," Diabetes, vol. 50, no. 5, pp. 928-936, 2001.

[50] L. C. Murtaugh, B. Z. Stanger, K. M. Kwan, and D. A. Melton, "Notch signaling controls multiple steps of pancreatic differentiation," Proceedings of the National Academy of Sciences of the United States of America, vol. 100, no. 25, pp. 14920 14925, 2003.

[51] D. Kopinke, M. Brailsford, J. E. Shea, R. Leavitt, C. L. Scaife, and L. C. Murtaugh, "Lineage tracing reveals the dynamic contribution of Hes1+ cells to the developing and adult pancreas," Development, vol. 138, no. 3, pp. 431-441, 2011.

[52] H. P. Shih, J. L. Kopp, M. Sandhu, P. A. Seymour, A. Grapin-Botton, and M. Sander, "A Notch-dependent molecular circuitry initiates pancreatic endocrine and ductal cell differentiation," Development, vol. 139, no. 14, pp. 24882499, 2012.

[53] C. Cras-Méneur, L. Li, R. Kopan, and M. A. Permutt, "Presenilins, Notch dose control the fate of pancreatic endocrine progenitors during a narrow developmental window," Genes and Development, vol. 23, no. 17, pp. 2088-2101, 2009.

[54] E. B. Harmon, Å. A. Apelqvist, N. G. Smart, X. Gu, D. H. Osborne, and S. K. Kim, "GDF11 modulates $\mathrm{Ngn}^{+}$islet progenitor cell number and promotes $\beta$-cell differentiation in pancreas development," Development, vol. 131, no. 24, pp. 6163-6174, 2004.

[55] K. A. Johansson, U. Dursun, N. Jordan et al., “Temporal control of neurogenin3 activity in pancreas progenitors reveals competence windows for the generation of different endocrine cell types," Developmental Cell, vol. 12, no. 3, pp. 457-465, 2007.

[56] J. M. Rukstalis and J. F. Habener, "Neurogenin3: a master regulator of pancreatic islet differentiation and regeneration," Islets, vol. 1, no. 3, pp. 177-184, 2009.

[57] S. Wang, J. Yan, D. A. Anderson et al., "Neurog3 gene dosage regulates allocation of endocrine and exocrine cell fates in the developing mouse pancreas," Developmental Biology, vol. 339, no. 1, pp. 26-37, 2010.

[58] M. Gouzi, Y. H. Kim, K. Katsumoto, K. Johansson, and A. Grapin-Botton, "Neurogenin3 initiates stepwise delamination of differentiating endocrine cells during pancreas development," Developmental Dynamics, vol. 240, no. 3, pp. 589-604, 2011.

[59] J. Magenheim, A. M. Klein, R. Ashery-Padan, G. Gu, and Y. Dor, "Ngn $3^{+}$endocrine progenitor cells control the fate and morphogenesis of pancreatic ductal epithelium," Developmental Biology, vol. 359, no. 1, pp. 26-36, 2011.

[60] S. B. Smith, R. Gasa, H. Watada, J. Wang, S. C. Griffen, and M. S. German, "Neurogenin3 and hepatic nuclear factor 1 cooperate in activating pancreatic expression of Pax4," Journal of Biological Chemistry, vol. 278, no. 40, pp. 3825438259, 2003.

[61] S. B. Smith, H. Watada, and M. S. German, "Neurogenin3 activates the islet differentiation program while repressing its own expression," Molecular Endocrinology, vol. 18, no. 1, pp. 142-149, 2004.

[62] H. P. Huang, M. Liu, H. M. El-Hodiri, K. Chu, M. Jamrich, and M. J. Tsai, "Regulation of the pancreatic islet-specific gene BETA2 (neuroD) by neurogenin 3," Molecular and Cellular Biology, vol. 20, no. 9, pp. 3292-3307, 2000.

[63] G. Mellitzer, S. Bonné, R. F. Luco et al., "IA1 is NGN3dependent and essential for differentiation of the endocrine pancreas," EMBO Journal, vol. 25, no. 6, pp. 1344-1352, 2006.

[64] R. Desgraz and P. L. Herrera, "Pancreatic neurogenin 3expressing cells are unipotent islet precursors," Development, vol. 136, no. 21, pp. 3567-3574, 2009.

[65] P. A. Seymour, K. K. Freude, M. N. Tran et al., "SOX9 is required for maintenance of the pancreatic progenitor cell pool," Proceedings of the National Academy of Sciences of the United States of America, vol. 104, no. 6, pp. 1865-1870, 2007.

[66] P. A. Seymour, K. K. Freude, C. L. Dubois, H. P. Shih, N. A. Patel, and M. Sander, "A dosage-dependent requirement for Sox9 in pancreatic endocrine cell formation," Developmental Biology, vol. 323, no. 1, pp. 19-30, 2008.

[67] N. Sander, L. Sussel, J. Conners et al., "Homeobox gene Nkx6.1 lies downstream of Nkx2.2 in the major pathway of $\beta$-cell formation in the pancreas," Development, vol. 127, no. 24, pp. 5533-5540, 2000. 
[68] A. E. Schaffer, K. K. Freude, S. B. Nelson, and M. Sander, "Nkx6 transcription factors and Ptfla function as antagonistic lineage determinants in multipotent pancreatic progenitors," Developmental Cell, vol. 18, no. 6, pp. 1022 $1029,2010$.

[69] M. A. Maestro, S. F. Boj, R. F. Luco et al., "Hnf6 and Tcf2 (MODY5) are linked in a gene network operating in a precursor cell domain of the embryonic pancreas," Human Molecular Genetics, vol. 12, no. 24, pp. 3307-3314, 2003.

[70] M. Maestro, C. Cardalda, S. Boj, R. Luco, J. Servitja, and J. Ferrer, "Distinct roles of HNF1 $\beta, \mathrm{HNF} 1 \alpha$, and HNF $4 \alpha$ in regulating pancreas development, $\beta$-cell function and growth," Endocrine Development, vol. 12, pp. 33-45, 2007.

[71] M. Solar, C. Cardalda, I. Houbracken et al., "Pancreatic exocrine duct cells give rise to insulin-producing beta cells during embryogenesis but not after birth," Developmental Cell, vol. 17, no. 6, pp. 849-860, 2009.

[72] J. L. Kopp, C. L. Dubois, E. Hao, F. Thorel, P. L. Herrera, and M. Sander, "Progenitor cell domains in the developing and adult pancreas," Cell Cycle, vol. 10, no. 12, pp. 1921-1927, 2011.

[73] S. Wang, J. N. Jensen, P. A. Seymour et al., "Sustained Neurog3 expression in hormone-expressing islet cells is required for endocrine maturation and function," Proceedings of the National Academy of Sciences of the United States of America, vol. 106, no. 24, pp. 9715-9720, 2009.

[74] F. J. Naya, H. P. Huang, Y. Qiu et al., "Diabetes, defective pancreatic morphogenesis, and abnormal enteroendocrine differentiation in BETA2/NeuroD-deficient mice," Genes and Development, vol. 11, no. 18, pp. 2323-2334, 1997.

[75] M. S. Gierl, N. Karoulias, H. Wende, M. Strehle, and C. Birchmeier, "The Zinc-finger factor Insm1 (IA-1) is essential for the development of pancreatic $\beta$ cells and intestinal endocrine cells," Genes and Development, vol. 20, no. 17, pp. 2465-2478, 2006.

[76] J. Soyer, L. Flasse, W. Raffelsberger et al., "Rfx6 is an Ngn3dependent winged helix transcription factor required for pancreatic islet cell development," Development, vol. 137, no. 2, pp. 203-212, 2010.

[77] S. B. Smith, H. Q. Qu, N. Taleb et al., "Rfx6 directs islet formation and insulin production in mice and humans," Nature, vol. 463, no. 7282, pp. 775-780, 2010.

[78] B. Sosa-Pineda, K. Chowdhury, M. Torres, G. Oliver, and P. Gruss, "The Pax4 gene is essential for differentiation of insulin-producing $\beta$ cells in the mammalian pancreas," Nature, vol. 386, no. 6623, pp. 399-402, 1997.

[79] J. Wang, L. Elghazi, S. E. Parker et al., "The concerted activities of Pax4 and Nkx2.2 are essential to initiate pancreatic $\beta$-cell differentiation," Developmental Biology, vol. 266, no. 1, pp. 178-189, 2004

[80] A. L. Greenwood, S. Li, K. Jones, and D. A. Melton, "Notch signaling reveals developmental plasticity of Pax4+ pancreatic endocrine progenitors and shunts them to a duct fate," Mechanisms of Development, vol. 124, no. 2, pp. 97-107, 2007.

[81] P. Collombat, A. Mansouri, J. Hecksher-Sørensen et al., "Opposing actions of Arx and Pax4 in endocrine pancreas development," Genes and Development, vol. 17, no. 20, pp. 2591-2603, 2003.

[82] P. Collombat, J. Hecksher-Sørensen, V. Broccoli et al., "The simultaneous loss of Arx and Pax4 genes promotes a somatostatin-producing cell fate specification at the expense of the $\alpha$ - and $\beta$-cell lineages in the mouse endocrine pancreas," Development, vol. 132, no. 13, pp. 2969-2980, 2005.
[83] S. Dhawan, S. Georgia, S. I. Tschen, G. Fan, and A. Bhushan, "Pancreatic beta cell identity is maintained by DNA methylation-mediated repression of Arx," Developmental Cell, vol. 20, no. 4, pp. 419-429, 2011.

[84] J. Liu, C. S. Hunter, A. Du et al., "Islet-1 regulates Arx transcription during pancreatic islet $\alpha$-cell development," Journal of Biological Chemistry, vol. 286, no. 17, pp. 1535215360, 2011.

[85] P. Collombat, J. Hecksher-Sørensen, J. Krull et al., "Embryonic endocrine pancreas and mature $\beta$ cells acquire $\alpha$ and PP cell phenotypes upon Arx misexpression," Journal of Clinical Investigation, vol. 117, no. 4, pp. 961-970, 2007.

[86] L. Sussel, J. Kalamaras, D. J. Hartigan-O’Connor et al., “Mice lacking the homeodomain transcription factor Nkx2.2 have diabetes due to arrested differentiation of pancreatic $\beta$ cells," Development, vol. 125, no. 12, pp. 2213-2221, 1998.

[87] C. S. Chao, Z. L. Loomis, J. E. Lee, and L. Sussel, "Genetic identification of a novel NeuroD1 function in the early differentiation of islet $\alpha, \mathrm{PP}$ and $\varepsilon$ cells," Developmental Biology, vol. 312, no. 2, pp. 523-532, 2007.

[88] S. Kordowich, P. Collombat, and A. Mansouri, "Arx and Nkx2.2 compound deficiency redirects pancreatic alphaand beta-cell differentiation to a somatostatin/ghrelin coexpressing cell lineage," BMC Developmental Biology, vol. 11, article 52, 2011.

[89] T. L. Mastraccia, C. L. Wilcoxb, L. Arnes et al., "Nkx2.2 and Arx genetically interact to regulate pancreatic endocrine cell development and endocrine hormone expression," Developmental Biology, vol. 359, no. 1, pp. 1-11, 2011.

[90] J. B. Papizan, R. A. Singer, S.-I. Tschen et al., "Nkx2.2 repressor complex regulates islet $\beta$-cell specification and prevents $\beta$-to- $\alpha$-cell reprogramming," Genes and Development, vol. 25 , no. 21, pp. 2291-2305, 2011.

[91] Y. Hang and R. Stein, "MafA and MafB activity in pancreatic $\beta$ cells," Trends in Endocrinology and Metabolism, vol. 22, no. 9, pp. 364-373, 2011.

[92] I. Artner, Y. Hang, M. Mazur et al., "MafA and MafB regulate genes critical to $\beta$-cells in a unique temporal manner," Diabetes, vol. 59, no. 10, pp. 2530-2539, 2010.

[93] I. Artner, J. Le Lay, Y. Hang et al., "An activator of the glucagon gene expressed in developing islet $\alpha$ - and $\beta$-cells," Diabetes, vol. 55, no. 2, pp. 297-304, 2006.

[94] W. Nishimura, T. Kondo, T. Salameh et al., "A switch from MafB to MafA expression accompanies differentiation to pancreatic $\beta$-cells," Developmental Biology, vol. 293, no. 2, pp. 526-539, 2006.

[95] Y. Abiko, M. Saitoh, M. Nishimura, M. Yamazaki, D. Sawamura, and T. Kaku, "Role of $\beta$-defensins in oral epithelial health and disease," Medical Molecular Morphology, vol. 40, no. 4, pp. 179-184, 2007.

[96] L. St-Onge, B. Sosa-Pineda, K. Chowdhury, A. Mansouri, and P. Gruss, "Pax6 is required for differentiation of glucagonproducing $\alpha$-cells in mouse pancreas," Nature, vol. 387, no. 6631, pp. 406-409, 1997.

[97] M. Sander, A. Neubüser, J. Kalamaras, H. C. Ee, G. R. Martin, and M. S. German, "Genetic analysis reveals that PAX6 is required for normal transcription of pancreatic hormone genes and islet development," Genes and Development, vol. 11, no. 13, pp. 1662-1673, 1997.

[98] R. S. Heller, M. Jenny, P. Collombat et al., "Genetic determinants of pancreatic E-cell development," Developmental Biology, vol. 286, no. 1, pp. 217-224, 2005.

[99] R. Ashery-Padan, X. Zhou, T. Marquardt et al., "Conditional inactivation of Pax6 in the pancreas causes early onset of 
diabetes," Developmental Biology, vol. 269, no. 2, pp. 479-488, 2004.

[100] J. C. Schisler, P. T. Fueger, D. A. Babu et al., "Stimulation of human and rat islet $\beta$-cell proliferation with retention of function by the homeodomain transcription factor Nkx6.1," Molecular and Cellular Biology, vol. 28, no. 10, pp. 3465-3476, 2008.

[101] A. E. Schaffer, A. J. Yang, F. Thorel, P. L. Herrera, and M. Sander, "Transgenic overexpression of the transcription factor Nkx6.1 in $\beta$-cells of mice does not increase $\beta$-cell proliferation, $\beta$-cell mass, or improve glucose clearance," Molecular Endocrinology, vol. 25, no. 11, pp. 1904-1914, 2011.

[102] T. Brun, I. Franklin, L. St.-Onge L. et al., “The diabetes-linked transcription factor PAX4 promotes $\beta$-cell proliferation and survival in rat and human islets," Journal of Cell Biology, vol. 167, no. 6, pp. 1123-1135, 2004.

[103] A. Du, C. S. Hunter, J. Murray et al., "Islet-1 is required for the maturation, proliferation, and survival of the endocrine pancreas," Diabetes, vol. 58, no. 9, pp. 2059-2069, 2009.

[104] U. Ahlgren, J. Jonsson, L. Jonsson, K. Simu, and H. Edlund, " $\beta$-cell-specific inactivation of the mouse Ipf1/Pdxl gene results in loss of the $\beta$-cell phenotype and maturity onset diabetes," Genes and Development, vol. 12, no. 12, pp. 17631768, 1998.

[105] Y.-P. Yang, F. Thorel, D. F. Boyer, P. L. Herrera, and C. V. E. Wright, "Context-specific $\alpha$ a-to- $\beta$-cell reprogramming by forced Pdx1 expression," Genes and Development, vol. 25, no. 16, pp. 1680-1685, 2011.

[106] S. Bonner-Weir, W. C. Li, L. Ouziel-Yahalom, L. Guo, G. C. Weir, and A. Sharma, " $\beta$-cell growth and regeneration: replication is only part of the story," Diabetes, vol. 59, no. 10, pp. 2340-2348, 2010.

[107] R. Desgraz, C. Bonal, and P. L. Herrera, “ $\beta$-Cell regeneration: the pancreatic intrinsic faculty," Trends in Endocrinology and Metabolism, vol. 22, no. 1, pp. 34-43, 2011.

[108] B. M. Desai, J. Oliver-Krasinski, D. D. De Leon et al., "Preexisting pancreatic acinar cells contribute to acinar cell, but not islet $\beta$ cell, regeneration," Journal of Clinical Investigation, vol. 117, no. 4, pp. 971-977, 2007.

[109] H. Mashima, H. Ohnishi, K. Wakabayashi et al., "Betacellulin and activin A coordinately convert amylase-secreting pancreatic AR42J cells into insulin-secreting cells," Journal of Clinical Investigation, vol. 97, no. 7, pp. 1647-1654, 1996.

[110] H. Mashima, H. Shibata, T. Mine, and I. Kojima, "Formation of insulin-producing cells from pancreatic acinar AR42J cells by hepatocyte growth factor," Endocrinology, vol. 137, no. 9, pp. 3969-3976, 1996.

[111] M. Rovira, S. G. Scott, A. S. Liss, J. Jensen, S. P. Thayer, and S. D. Leach, "Isolation and characterization of centroacinar/terminal ductal progenitor cells in adult mouse pancreas," Proceedings of the National Academy of Sciences of the United States of America, vol. 107, no. 1, pp. 75-80, 2010.

[112] D. Hesselson, R. M. Anderson, and D. Y. R. Stainier, "Suppression of Ptfla activity induces acinar-to-endocrine conversion," Current Biology, vol. 21, no. 8, pp. 712-717, 2011.

[113] S. Georgia and A. Bhushan, " $\beta$ cell replication is the primary mechanism for maintaining postnatal $\beta$ cell mass," Journal of Clinical Investigation, vol. 114, no. 7, pp. 963-968, 2004.

[114] D. A. Cano, I. C. Rulifson, P. W. Heiser et al., "Regulated $\beta$ cell regeneration in the adult mouse pancreas," Diabetes, vol. 57, no. 4, pp. 958-966, 2008.
[115] C. S. Lee, D. D. De León, K. H. Kaestner, and D. A. Stoffers, "Regeneration of pancreatic islets after partial pancreatectomy in mice does not involve the reactivation of neurogenin-3," Diabetes, vol. 55, no. 2, pp. 269-272, 2006.

[116] M. V. Joglekar, V. S. Parekh, S. Mehta, R. R. Bhonde, and A. A. Hardikar, "MicroRNA profiling of developing and regenerating pancreas reveal post-transcriptional regulation of neurogenin3," Developmental Biology, vol. 311, no. 2, pp. 603-612, 2007.

[117] S. Rieck and K. H. Kaestner, "Expansion of $\beta$-cell mass in response to pregnancy," Trends in Endocrinology and Metabolism, vol. 21, no. 3, pp. 151-158, 2010.

[118] S. K. Karnik, H. Chen, G. W. McLean et al., "Menin controls growth of pancreatic $\beta$-cells in pregnant mice and promotes gestational diabetes mellitus," Science, vol. 318, no. 5851, pp. 806-809, 2007.

[119] S. Abouna, R. W. Old, S. Pelengaris et al., "Non- $\beta$-cell progenitors of $\beta$-cells in pregnant mice," Organogenesis, vol. 6, no. 2, pp. 125-133, 2010.

[120] M. Teta, S. Y. Long, L. M. Wartschow, M. M. Rankin, and J. A. Kushner, "Very slow turnover of $\beta$-cells in aged adult mice," Diabetes, vol. 54, no. 9, pp. 2557-2567, 2005.

[121] K. Tanigawa, S. Nakamura, M. Kawaguchi, G. Xu, S. Kin, and K. Tamura, "Effect of aging on B-cell function and replication in rat pancreas after 90\% pancreatectomy," Pancreas, vol. 15, no. 1, pp. 53-59, 1997.

[122] S. I. Tschen, S. Dhawan, T. Gurlo, and A. Bhushan, "Agedependent decline in $\beta$-cell proliferation restricts the capacity of $\beta$-cell regeneration in mice," Diabetes, vol. 58, no. 6, pp. 1312-1320, 2009.

[123] M. M. Rankin and J. A. Kushner, "Adaptive $\beta$-cell proliferation is severely restricted with advanced age," Diabetes, vol. 58, no. 6, pp. 1365-1372, 2009.

[124] J. A. Kushner, M. A. Ciemerych, E. Sicinska et al., "Cyclins D2 and D1 are essential for postnatal pancreatic $\beta$-cell growth," Molecular and Cellular Biology, vol. 25, no. 9, pp. 3752-3762, 2005.

[125] I. Cozar-Castellano, N. Fiaschi-Taesch, T. A. Bigatel et al., "Molecular control of cell cycle progression in the pancreatic $\beta$-cell," Endocrine Reviews, vol. 27, no. 4, pp. 356-370, 2006.

[126] I. Cozar-Castellano, K. K. Takane, R. Bottino, A. N. Balamurugan, and A. F. Stewart, "Induction of beta-cell proliferation and retinoblastoma protein phosphorylation in rat and human islets using adenovirus-mediated transfer of cyclindependent kinase-4 and cyclin D1," Diabetes, vol. 53, no. 1, pp. 149-159, 2004.

[127] S. Bonner-Weir, L. A. Baxter, G. T. Schuppin, and F. E. Smith, "A second pathway for regeneration of adult exocrine and endocrine pancreas: a possible recapitulation of embryonic development," Diabetes, vol. 42, no. 12, pp. 1715-1720, 1993.

[128] Y. Dor and D. A. Melton, "Facultative endocrine progenitor cells in the adult pancreas," Cell, vol. 132, no. 2, pp. 183-184, 2008.

[129] H. P. Huang, K. Chu, E. Nemoz-Gaillard, D. Elberg, and M. J. Tsai, "Neogenesis of $\beta$-cells in adult BETA2/NeuroDdeficient mice," Molecular Endocrinology, vol. 16, no. 3, pp. 541-551, 2002.

[130] J. A. Kushner, G. C. Weir, and S. Bonner-Weir, "Ductal origin hypothesis of pancreatic regeneration under attack," Cell Metabolism, vol. 11, no. 1, pp. 2-3, 2010.

[131] D. Kopinke and L. C. Murtaugh, "Exocrine-to-endocrine differentiation is detectable only prior to birth in the uninjured mouse pancreas," BMC Developmental Biology, vol. 10, article $38,2010$. 
[132] J. L. Kopp, C. L. Dubois, A. E. Schaffer et al., "Sox9+ ductal cells are multipotent progenitors throughout development but do not produce new endocrine cells in the normal or injured adult pancreas," Development, vol. 138, no. 4, pp. 653-665, 2011.

[133] M. Reichert and A. K. Rustgi, "Pancreatic ductal cells in development, regeneration, and neoplasia," Journal of Clinical Investigation, vol. 121, no. 12, pp. 4572-4578, 2011.

[134] R. W. Gelling, X. Q. Du, D. S. Dichmann et al., "Lower blood glucose, hyperglucagonemia, and pancreatic $\alpha$ cell hyperplasia in glucagon receptor knockout mice," Proceedings of the National Academy of Sciences of the United States of America, vol. 100, no. 3, pp. 1438-1443, 2003.

[135] M. Furuta, H. Yano, A. Zhou et al., "Defective prohormone processing and altered pancreatic islet morphology in mice lacking active SPC2," Proceedings of the National Academy of Sciences of the United States of America, vol. 94, no. 13, pp. 6646-6651, 1997.

[136] Y. Hayashi, M. Yamamoto, H. Mizoguchi et al., "Mice deficient for glucagon gene-derived peptides display normoglycemia and hyperplasia of islet $\alpha$-cells but not of intestinal L-cells," Molecular Endocrinology, vol. 23, no. 12, pp. 19901999, 2009.

[137] G. C. Webb, M. S. Akbar, C. Zhao, H. H. Swift, and D. F. Steiner, "Glucagon replacement via micro-osmotic pump corrects hypoglycemia and $\alpha$-cell hyperplasia in prohormone convertase 2 knockout mice," Diabetes, vol. 51, no. 2, pp. 398 405, 2002.

[138] M. Vincent, Y. Guz, M. Rozenberg et al., "Abrogation of protein convertase 2 activity results in delayed islet cell differentiation and maturation, increased $\alpha$-cell proliferation, and islet neogenesis," Endocrinology, vol. 144, no. 9, pp. 40614069, 2003.

[139] F. Thorel, N. Damond, S. Chera, A. Wiederkehr, C. B. Wollheim, and P. L. Herrera, "Normal glucagon signaling and $\beta$-cell function after near-total $\alpha$-cell ablation in adult mice," Diabetes, vol. 60, no. 11, pp. 2872-2882, 2011.

[140] J. Lu, P. L. Herrera, C. Carreira et al., "Alpha cell-specific Men1 ablation triggers the transdifferentiation of glucagonexpressing cells and insulinoma development," Gastroenterology, vol. 138, no. 5, pp. 1954-1965, 2010.

[141] Z. Liu and J. F. Habener, "Alpha cells beget beta cells," Cell, vol. 138, no. 3, pp. 424-426, 2009.

[142] Z. Liu, W. Kim, Z. Chen et al., "Insulin and glucagon regulate pancreatic $\alpha$-cell proliferation," PLOS ONE, vol. 6, no. 1, Article ID e16096, 2011.

[143] W. Gepts and J. De Mey, "Islet cell survival determined by morphology. An immunocytochemical study of the islets of Langerhans in juvenile diabetes mellitus," Diabetes, vol. 27, no. 1, pp. 251-261, 1978

[144] Z. Li, F. A. Karlsson, and S. Sandler, "Islet loss and alpha cell expansion in type 1 diabetes induced by multiple low-dose streptozotocin administration in mice," Journal of Endocrinology, vol. 165, no. 1, pp. 93-99, 2000.

[145] J. F. Habener and V. Stanojevic, " $\alpha$-cell role in $\beta$-cell generation and regeneration," Islets, vol. 4, no. 3, pp. 188198, 2012. 


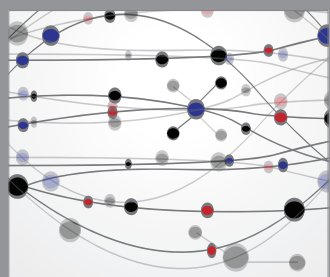

The Scientific World Journal
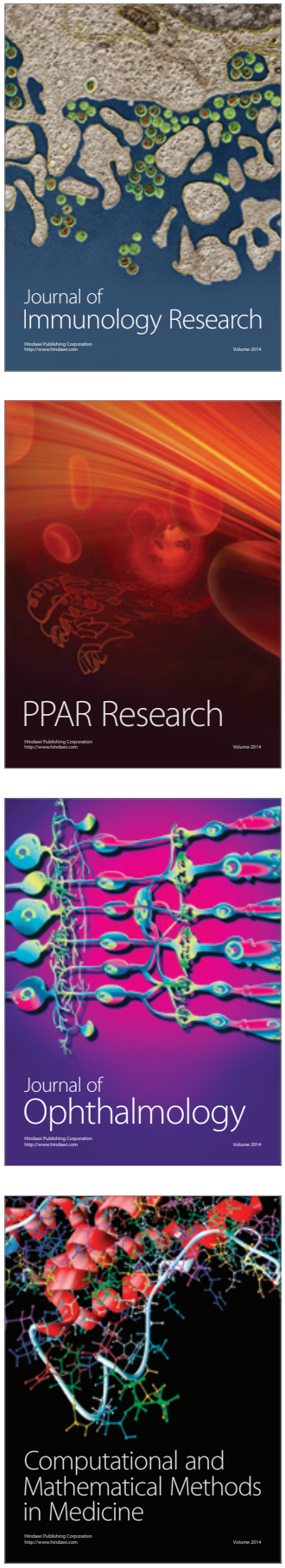

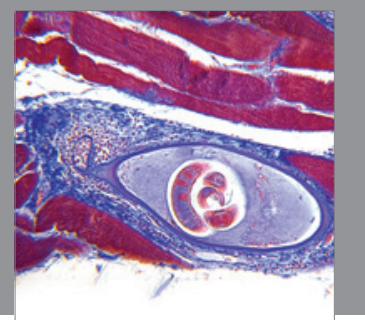

Gastroenterology

Research and Practice
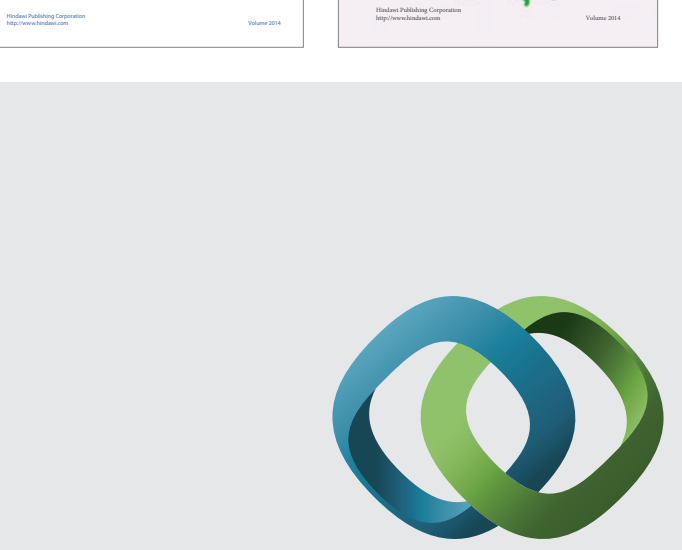

\section{Hindawi}

Submit your manuscripts at

http://www.hindawi.com
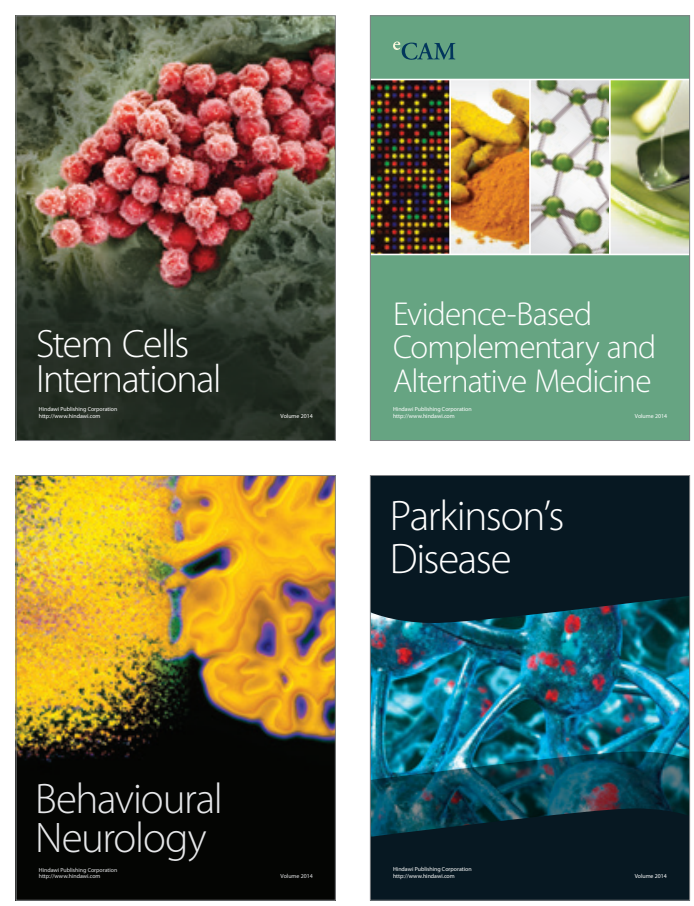

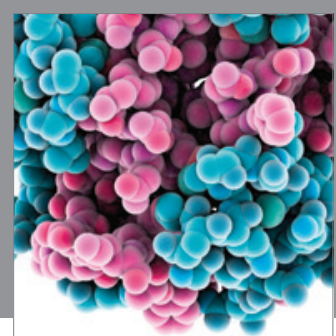

Journal of
Diabetes Research

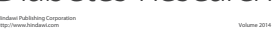

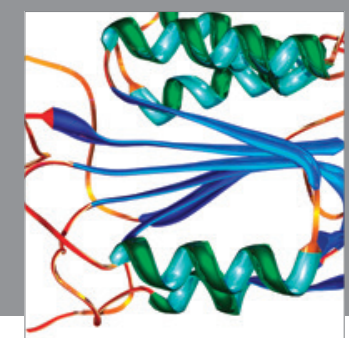

Disease Markers
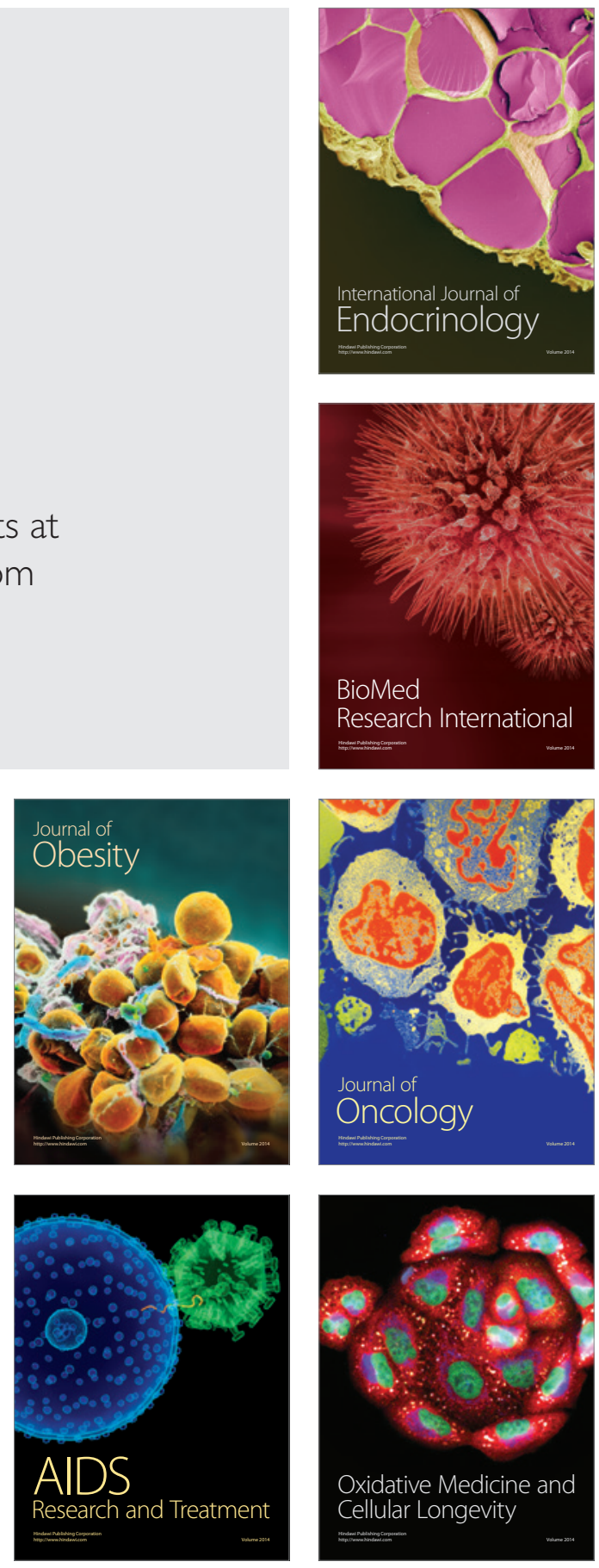